
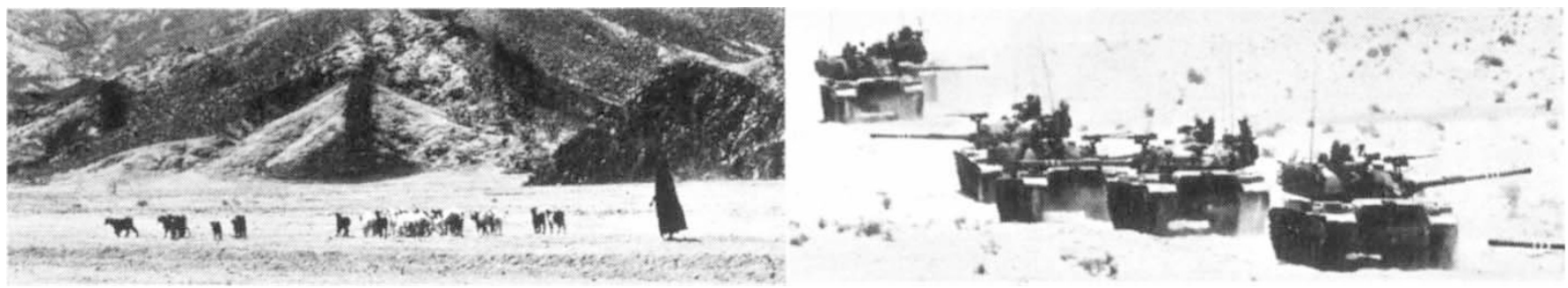

Sinai in peace and in war: one plan was to make it an Arab-Israeli "national park"

\title{
Israel wants scientific cooperation with the Arabs
}

ISRAEL scientists see the outcome of the Camp David talks as a unique challenge and chance for mutual cooperation-a result which may, at first, seem paradoxical, since the settlement will mean handing over to Egyptian control one of the most strictly protected conservation areas in the world.

During the 12 years that Sinai has been under Israeli control, environmental restrictions have been so strict that not even a single shell could legally be removed from the beach without special permission. The fragile ecology of the area has been extensively studied, and investigations of the "solar lake", a few kilometres south of the pre-1967 frontier have provided a new concept in the commercial use of solar energy. For this lake has a natural stratification of salinity allowing bottom water temperature to build up to more than $60^{\circ} \mathrm{C}$, without convective heating of the upper layers which remain at approximately $20^{\circ} \mathrm{C}$. Not surprisingly, at the international conference on the application of solar energy held earlier this month at the Technion-Israel's institute of technology-there was a whole session devoted to artificial solar ponds, which, it is hoped, will ultimately be used for electricity generation, desalination of sea-water and for low temperature industrial heat production.

As far as the ecology of the Sinai is concerned, the non-governmental Society for the Protection of Nature, which has maintained three field study centres in the Sinai-at Na'ama, Yamit, and Santa Katarina-is willing to extend to the Egyptians any assistance they may require. Indeed, Professor Amotz Zahavi told Nature that several years ago, the society suggested that the Sinai should be made into an "international park for peace" under joint Israeli/F.gyptian control.

For some years, said Professor Zahavi. the society has becn passing on its findings and ideas on conservation to the Israeli authorities. Now, with the hand-over to the Egyptians, their experts would be willing to stay on at the field centres, working in collaboration with the Egyptians for the sake of conservation. Professor Zahavi stressed that the Israeli teams have no idea how the Egyptians will react to this proposal. "So far as we know, conservation is not yet very well developed in Egypt," he said, a further reason why his society is so concerned to help.

Israel has an impressive record in desert reclamation and the cultivation of marginal lands. With perhaps onethird of the world's cultivable land threatened with desertification, Israeli environmentalists describe as tragic the Arab walk-out from last year's conference on desertification when an Israeli delegate rose to speak.

At Haifa, the Kogan-Rose desalination pilot plant, which uses a counterflow system to eliminate the need for expensive copper-tubing heat-exchangers, has proved its worth, and plans are underway to construct a fullscale installation capable of delivering some million cubic metres per day. The main question to be decided now is where to build it. While such questions are, of course. matters for the politicians to decide, Professor Abraham Kogan, the designer, speaks of a possible joint Israeli-Egyptian venture.

Indeed, the consensus of Israeli scientific opinion seems to run ahead of the formal political situation. Last summer, in his report to the international board of governors of the Technion, made on the occasion of the 30th anniversary of Israeli independence, the Technion president, Amos Horev, stressed that technological cooperation "could well be put into effect with Arab neighbours even in advance of formal peace". Ecologists and technologists are already looking hopefully towards other frontiers. The Dead Sea potash works, for example, which produces fertilizers from evaporated Dead Sea brines, must use a certain amount of non-saline water in the extraction process. With a growing world demand for fertilizer and a virtually inexhaustible supply of raw material, it is small wonder that some engineers think longingly of the fresh water supply, just across the Jordanian frontier, which in British Mandate times was actually piped to the forerunner of the present potash works (then sited at the northern end of the Dead Sea).
Jordan is known to be considering a potash works of her own-a joint development would be more economical and also a powerful factor in the continued peace of the area.

Likewise. marine ecologists in the Gulf of Aqaba stress that however carefully they monitor the tankers discharging at the Eilat oil terminal, the gulf is narrow, and has no real tidal scour. A joint protection and monitoring programme involving all the littoral states-Israel, Jordan, Saudi Arabia, and Egypt-is the best hope of avoiding major pollution in this part of the gulf.

And, looking even further ahead, Professor $Y$. Avnimelech of the Kinneret water research project even mentioned the old Johnstone plan of Mandate times, by which the river Yarmuk would be diverted into Kinneret, the augmented waters of which could then be used for the benefit of what now constitutes both Israel and Jordan. Since the Kinneret now serves as the sole fresh water source for Israel's national water grid, and the Israeli water economy is so tight that brackish and waste water irrigation is an increasing necessity, even the most academic allusion to such a scheme reflects a considerable committment to the idea of cooperation.

Such a commitment, however, is more than a pipe-dream of a few scientists, however far ahead the realisation may be, the Israeli government undoubtedly endorses the underlying principle. Addressing the international congress of ecology, which was held in Jerusalem during the week of the Camp David talks, Mr Yigal Yadin, the Israeli deputy prime minister, stressed that "ecology has no national boundaries". After outlining Israel's considerable achievement in developing the country without major ecological damage, while at the same time extending aid to such third world countries as would accept it, he concluded

"We are yearning for peace so that we can strive for a better world. Let us endeavour when peace comes on earth -if the earth still be there-we may be more worthy to enjoy it".

Vera Rich 